\title{
Antibacterial properties of contact defensive secretions in neotropical Crematogaster ants
}

Quinet Y (1), Vieira RHSF (2), Sousa MR (3), Evangelista-Barreto NS (3), Carvalho FCT (2), Guedes MIF (3), Alves CR (3), de Biseau JC (4), Heredia A (1)

(1) Superior Institute of Biomedical Sciences, State University of Ceará, Fortaleza, Ceará State, Brazil; (2) Institute of Marine Sciences, Federal University of Ceará, Fortaleza, Ceará State, Brazil; (3) Laboratory of Human Biochemistry, State University of Ceará, Fortaleza, Ceará State, Brazil; (4) Evolutionary Eco-Ethology, Free University of Brussels, Brussels, Belgium.

\begin{abstract}
Crematogaster ants use their contact venoms to compete with other ants. Although those venoms are used primarily as repellent and toxic secretions, they may have other functions. The present study aimed to test the antibacterial property of abdominal venom of three neotropical Crematogaster ant species (C. distans, C. pygmaea and C. rochai) against gram-negative (Escherichia coli and Pseudomonas aeruginosa) and gram-positive (Enterococcus faecalis and Staphylococcus aureus) bacteria. Sterile filter paper was soaked with C. distans, C. pygmaea or C. rochai crude venom and placed on an agar dish that was inoculated with bacterial suspensions. The agar dish was incubated overnight at $37^{\circ} \mathrm{C}$ and examined for zones of growth inhibition. For each tested venom and bacterial strain, three venom concentrations were used, with six replicates for each concentration: 1, 2 and 4 DGE (Dufour's gland equivalent). The venom of C. pygmaea, but not those of $C$. rochai and $C$. distans, inhibited the growth of all tested gram-positive and gram-negative bacterial strains. This is the first evidence of antibacterial properties of contact venoms in Crematogaster ants and it supports the claim that ant venoms are multifunctional. It is hypothesized that only C. pygmaea venom showed antibacterial activities due to its nesting habits.
\end{abstract}

Key words: Hymenoptera, Formicidae, Crematogaster, sting apparatus, contact venoms.

Crematogaster Lund, 1831 is the fourth most speciose ant genus. Many species of this genus are dominant elements of tropical ant communities $(1,2)$. All of them possess the Formicidae sting apparatus in a derived state: while the most primitive ants use their sting to inject venom produced by the poison gland, Crematogaster species possess a spatulate sting utilized to apply contact defensive secretions from their hypertrophied Dufour's gland directly onto the integument of enemies $(3,4)$. This is facilitated by the unique arrangement of postpetiole and gaster, which allows the gaster and the sting to be pointed in nearly all directions $(3,4)$.

Chemical analysis of the Dufour's gland secretions of Crematogaster species from Europe,
Papua New Guinea, Brazil and Kenya showed high diversity of defensive compounds including longchain conjugated dienones, furanocembranoid diterpenes and trihydroxylated cyclohexane derivatives (5-10). Crematogaster contact venoms seem to be used primarily as repellent and toxic secretions in interference competition with other ants, as demonstrated in species from South America (C. rochai Forel, 1903, C. distans Mayr, 1879 and C. pygmaea Forel, 1904) and Europe [C. scutellaris (Olivier, 1792)] $(11,12)$.

However, Crematogaster venoms could have other functions, since multifunctional venoms seem to be the rule in ants (13). In Solenopsis invicta Buren, 1972 and Pachycondyla goeldii (Forel, 1912), for example, defensive and/or 
offensive venoms are also used as antiseptic substances for nest and brood hygiene $(14,15)$.

The three species analyzed in the present study (C. distans, C. pygmaea and C. rochai) are common in northeastern Brazil. Crematogaster pygmaea is a soil-nesting species found in open sandy areas of the coastal zone, whereas $C$. rochai and $C$. distans are two sympatric arboreal species found in "caatinga", a savanna-like formation (16, 17). In C. distans, the main compound found in the Dufour's gland is a long-chain derivative (acetylenic tetraene) linked to a primary acetate [(13E, 15E, 18Z,20Z)-1-hydroxypentacosa13,15,18,20-tetraen-11-yn-4-one 1-acetate], while in $C$. rochai, the main compounds are two furanocembranoid diterpenes $\left[\left(1 R^{\star}, 11 R^{\star}, 12 R^{\star}\right)-6,19: 11,12\right.$-bisepoxycembra3,6,8(19),15-tetraene, and $\left(1 R^{\star}, 3 S^{*}, 4 S^{*}\right)-3,4: 6,19$ bisepoxycembra-,6,8(19),11,15-tetraene] $(7,8)$.

In C. pygmaea, preliminary results obtained with thin layer chromatography showed that the Dufour's gland chemistry is similar to that of the European species C. scutellaris, in which a reaction takes place on the sting at the time of venom emission. Briefly, long-chain primary acetates [a series of $\mathrm{C}_{23}$ long-chain derivatives, with a $(E, E)$-cross-conjugated dienone linked to a primary acetate function] from the Dufour's gland are converted to highly electrophilic aldehydes by enzymes (an acetate esterase and an alcohol oxidase) from the poison gland (18). In C. scutellaris, and probably also in C. pygmaea, as indicated by the strong smell of acetic acid when ants are disturbed (especially when nests are excavated in the field), the acetic acid released via hydrolysis of the primary acetates acts as an alarm pheromone (18). In this study, we investigated the antibacterial properties of $C$. distans, C. rochai and C. pygmaea venom.

Colonies of C. pygmaea were collected on the campus of the State University of Ceará, in Fortaleza (WGS: $03^{\circ} 47^{\prime} \mathrm{S} 38^{\circ} 33^{\prime} \mathrm{W}$ ), while those of $C$. distans and $C$. rochai were collected at Pentecoste (WGS: $03^{\circ} 48^{\prime} \mathrm{S} 39^{\circ} 21^{\prime} \mathrm{W}$ ), about $70 \mathrm{~km}$ from Fortaleza. For each Crematogaster species, two colonies were maintained in the laboratory, in round plastic containers $(23 \mathrm{~cm}$ high and 32 $\mathrm{cm}$ in diameter) with test tubes (C. pygmaea) or pieces of abandoned nests of Nasutitermes Dudley, 1890 (C. distans and C. rochai) as nesting places. Colonies were fed on sugar solution, water and freshly killed cockroaches.
Two gram-negative (Escherichia coli ATCC 25922 and Pseudomonas aeruginosa ATCC 27853) and two gram-positive (Enterococcus faecalis ATCC 29212 and Staphylococcus aureus ATCC 25923) strains were used to test the antibacterial property of the three venoms. Bacterial cultures were stored in tryptic soy agar (TSA - Difco - Becton, Dickinson and Company, France) at BOD (biochemical oxygen demand incubator) $23^{\circ} \mathrm{C}$ and later renewed to be used in the antibacterial assays.

Direct inoculums of bacterial suspensions were prepared to match the turbidity of a McFarland 0.5 standard. A sterile cotton swab was dipped into the suspension, pressed and rotated firmly against the side of the tube to remove excess inoculum from the swab, and swabbed evenly over the surface of a Mueller-Hinton agar plate (19). After inoculation, a sterile filter paper (2 x $2 \mathrm{~mm}$ ) was soaked with Crematogaster crude venom and placed on an agar dish (one paper per dish), and incubated overnight at $37^{\circ} \mathrm{C}$ and examined for a zone of growth inhibition.

In order to transfer the venom of one Crematogaster worker to a filter paper, the latter was first seized with forceps. With another forceps, the ant was seized in the thorax region. This procedure induced the emission of venom on the sting, which was subsequently rubbed against the filter paper until no more venom was released. The total volume of venom secreted by one worker was assumed to represent the content of one Dufour's gland and was called a Dufour's gland equivalent (DGE). Different individuals were used when more than 1 DGE was transferred to the filter paper.

For each tested venom and bacterial strain, three venom concentrations were used, with six replicates for each concentration: 1, 2 and 4 DGE. In separate agar dishes, sterile papers $(2 \times 2 \mathrm{~mm})$ without venom (one paper per dish; six replicates for each bacterial strain) were used as controls (24-hour incubation time).

The Kruskal-Wallis test was used to compare the mean inhibition zone diameters obtained at each DGE concentration, with the four bacterial strains, and the mean inhibition zone diameters obtained for each bacterial strain, with the three DGE concentrations. The frequency of positive replicates (i.e. with inhibition of bacterial growth) in treatment experiments, and the frequency of positive replicates in control experiments 
(without venom) were compared using the Fisher exact test.

Our results showed that the venom of $C$. pygmaea, but not those of C. rochai and C. distans, inhibited the growth of all gram-positive and gram-negative bacterial strains tested. While 1 DGE was active (i.e. showed a significant difference between the frequency of treatment replicates with effect and the frequency of control replicates with effect) only on $S$. aureus (Fisher exact test, $\mathrm{p}<0.05), 4$ DGE resulted in 100\% inhibition of all bacterial strains (Table 1). The inhibition zone diameter obtained for all bacterial strains tested with 2 or 4 DGE was nearly twice or three times that obtained with $1 \mathrm{DGE}$, and that obtained for S. aureus with 1, 2 or 4 DGE was always higher than the other three bacterial strains (Table 1). However, no significant difference was observed among the three venom concentrations, whatever the bacterial strain, nor among the four bacterial strains, regardless of the venom concentration (Kruskal-Wallis test, $\mathrm{p}>0.05$ ) (Table 1).

Most ants live in warm and humid environments that favor proliferation of pathogenic microorganisms. Furthermore, social characteristics of ant colonies such as high population density, relatedness of colony members and concentration of potentially contaminated food items make those insects a good medium for rapid spread of infectious diseases through the colony (20). To protect their colonies from pathogens, ants have developed effective defense mechanisms including the production of compounds with antibiotic properties (13).

One of the main sources of antiseptic substances in ants is the metapleural gland (21, 22). In Crematogaster deformis Roger, 1857, for example, the hypertrophied metapleural glands contain a mixture of phenols that possess antiseptic and repellent activities (23). The poison gland is another common source of antimicrobial substances in ants like Solenopsis invicta, Pachycondyla goeldii and Myrmecia pilosula Smith, F., 1858. In S. invicta, alkaloid venoms applied to eggs by the queen inhibit the growth of entomopathogenic fungi (14). In P. goeldii, the venom contains peptides (ponericines) with strong antimicrobial properties that may act as cleaning agents before prey is brought into the nest (15). In $M$. pilosula, peptides were found to present a broad-spectrum antimicrobial activity against gram-positive and gram-negative bacteria (24). Besides, peptides with antimicrobial activities are widespread in the venom of other arthropods, such as the social wasp Agelaia pallipes pallipes (Olivier, 1792), the wolf spiders

Table 1. Antibacterial activity of three concentrations of Crematogaster pygmaea crude venom. Data are reported as the mean $\pm S D(n=6)$. The number of replicates that produced inhibition zone is indicated in parentheses

\begin{tabular}{|c|c|c|c|c|c|}
\hline \multirow[t]{2}{*}{ Bacteria } & \multicolumn{5}{|c|}{ Inhibition zone diameter (mm) } \\
\hline & $1 \mathrm{DGE}$ & $2 \mathrm{DGE}$ & $4 \mathrm{DGE}$ & & Control \\
\hline \multicolumn{6}{|l|}{ Gram-positive } \\
\hline Staphylococcus aureus & $4.8 \pm 2.71$ & $8.5 \pm \frac{3.67}{(6)^{* * *}}$ & $\begin{array}{c}7.2 \pm 3.19 \\
(6)^{* *}\end{array}$ & NS & 0 \\
\hline Enterococcus faecalis & $\begin{array}{c}1.5 \pm 2.35 \\
(2)^{N S}\end{array}$ & $4.3 \pm 2.25$ & $\begin{array}{c}4.3 \pm 0.82 \\
(6)^{* *}\end{array}$ & NS & 0 \\
\hline \multicolumn{6}{|l|}{ Gram-negative } \\
\hline Escherichia coli & $\begin{array}{c}2.5 \pm 2.81 \\
(3)^{N S}\end{array}$ & $4.0 \underset{(5)^{* *}}{ \pm} 2.37$ & $5.7 \frac{ \pm}{(6)^{* *}}$ & NS & 0 \\
\hline \multirow[t]{2}{*}{ Pseudomonas aeruginosa } & $\begin{array}{c}2.7 \pm 2.07 \\
(4)^{N S}\end{array}$ & $4.5 \pm 2.43$ & $5.3 \pm 1.21$ & NS & 0 \\
\hline & NS & NS & NS & & \\
\hline
\end{tabular}

DGE: Dufour's gland equivalent; NS: $p>0.05$ - Kruskal-Wallis test; ${ }^{* *} p<0.05 ;{ }^{N s}$ : $p>0.05$ - Fisher exact test. 
Lycosa carolinensis Walckenaer, 1805 and L. singoriensis (Laxmann, 1770), and the scorpion Pandinus imperator (Koch, 1841) (25-28).

In the current study, evidence that contact venoms produced by Crematogaster ants possess antibacterial properties is presented for the first time. Interestingly, only the venom of C. pygmaea showed antibacterial activity. This fact could possibly be related to the chemical differences among venoms or/and different nesting habits. Crematogaster pygmaea is a ground-dwelling species that nests in humid and warm soils, possibly with higher exposure to pathogenic microorganisms than $C$. distans and C. rochai, which live in drier arboreal nests in semi-arid environments $(2,16,17)$. Furthermore, $C$. distans and C. rochai are frequently found in Nasutitermes nests that could already be impoverished in microorganisms due to antimicrobial substances produced by the frontal glands of termite soldiers $(17,29)$.

In conclusion, the present results suggest that toxic repellent secretions produced by the hypertrophied Dufour's gland of C. pygmaea may also be used as antimicrobial agents for nest hygiene. The spatulate sting and the extreme gaster flexibility could be particularly suited to apply antimicrobial compounds on surfaces such as nest walls, prey, or brood cuticle.

\section{ACKNOWLEDGMENTS}

We thank Dr. Ana Maria S. Assreuy and Dr. Yves Roisin for reviewing a draft of the manuscript and improving the English text, as well as the three anonymous reviewers whose suggestions greatly improved our manuscript.

\section{COPYRIGHT}

(c) CEVAP 2012

\section{SUBMISSION STATUS}

Received: April 4, 2012.

Accepted: August 20, 2012.

Abstract published online: September 3, 2012. Full paper published online: November 30, 2012.

\section{CONFLICTS OF INTEREST}

The authors declare no conflicts of interest.

\section{FINANCIAL SOURCE}

Ana Heredia was supported by a fellowship (DCR-CNPq) and Yves Quinet by a grant from the
National Council for Scientific and Technological Development (CNPq), project n. 473939/2004-5.

\section{CORRESPONDENCE TO}

Yves Patric Quinet, Av. Paranjana, 1700, Fortaleza, CE, 60740-000, Brasil. Phone: +55 8531019749. Fax: +55 853101 9810. Email: yvesq@terra.com. br.

\section{REFERENCES}

1. Bolton B. A taxonomic and zoogeographical census of the extant ant taxa (Hymenoptera: Formicidae). J Nat Hist. 1995;29(4):1037-56.

2. Longino JT. The Crematogaster (Hymenoptera, Formicidae, Myrmicinae) of Costa Rica. Zootaxa. 2003;151:1-150.

3. Buren WF. A review of the species of Crematogaster, sensu stricto, in North America (Hymenoptera: Formicidae) Part I. JNY Entomol Soc. 1958;66(34):119-34.

4. Buschinger A, Maschwitz U. Defensive behaviour and defensive mechanisms in ants. In: Hermann HR, editor. Defensive mechanisms in social insects. New York: Praeger; 1984. p. 95-100.

5. Daloze D, Kaisin M, Detrain C, Pasteels JM. Chemical defence in the three European species of Crematogaster ants. Experientia. 1991;47(10):1082-9.

6. Leclercq S, Braekman JC, Kaisin M, Daloze D, Detrain C, de Biseau JC, et al. Venom constituents of three species of Crematogaster ants from Papua New Guinea. J Nat Prod. 1997;60(11):1143-47.

7. Daloze D, de Biseau JC, Leclercq S, Braekman JC, Quinet Y, Pasteels JM. (13E,15E,18Z,20Z)-1Hydroxypentacosa-13,15,18,20-tetraen-11-yn-4-one 1 -acetate, from the venom of a Brazilian Crematogaster ant. Tetrahedron Lett. 1998;39(26):4671-2.

8. Leclercq S, Braekman JC, Daloze D, de Biseau JC, Pasteels JM, Quinet Y, et al. Furanocembrenoid diterpenes as defensive compounds in the Dufour's gland of the ant Crematogaster brevispinosa rochai. Tetrahedron. 2000;56:2037-42.

9. Leclercq S, de Biseau JC, Daloze D, Braekman JC, Quinet Y, Pasteels JM. Five new furanocembrenoids from the venom of the ant Crematogaster brevispinosa ampla from Brazil. Tetrahedron Lett. 2000;41(5):6337.

10. Laurent P, Hamdani A, Braekman JC, Daloze D, Isbell LA, de Biseau JC, et al. New 1-alk(en)yl-1,3,5trihydroxycyclohexanes from the Dufour gland of the African ant Crematogaster nigriceps. Tetrahedron Lett. 2003;44:1383-6.

11. Marlier JF, Quinet Y, de Biseau JC. Defensive behaviour and biological activities of the abdominal secretion in the ant Crematogaster scutellaris (Hymenoptera: Myrmicinae). Behav Processes. 2004;67(3):427-40.

12. Heredia A, de Biseau JC, Quinet Y. Toxicity of the venom in three neotropical Crematogaster ants (Formicidae: Myrmicinae). Chemoecology. 2005;15(4):235-42.

13. Blum MS. Semiochemical parsimony in the 
Arthropoda. Annu Rev Entomol. 1996;41:353-74.

14. Vander Meer RK, Morel L. Ant queens deposit pheromones and antimicrobial agents on eggs. Naturwissenschaften. 1995;82(2):93-5.

15. Orivel J, Redeker V, Le Caer JP, Krier F, Revol-Junelles $\mathrm{AM}$, Longeon A, et al. Ponericins, new antibacterial and insecticidal peptides from the venom of the ant Pachycondylagoeldii.J Biol Chem.2001;276(21):178239.

16. Quinet Y, Hamidi R, Ruiz-Gonzales MX, de Biseau JC, Longino JT. Crematogaster pygmaea (Hymenoptera: Formicidae: Myrmicinae), a highly polygynous and polydomous Crematogaster from northeastern Brazil. Zootaxa. 2009;2075:45-54.

17. Quinet Y, Tekule N, de Biseau JC. Behavioural interactions between Crematogaster brevispinosa rochai Forel (Hymenoptera: Formiciade) and two Nasutitermes species (Isoptera: Termitidae). J Insect Behav. 2005;18(1):1-17.

18. Pasteels JM, Daloze D, Boevé JL. Aldehydic contact poisons and alarm pheromone of the ant Crematogaster scutellaris (Hymenoptera: Myrmicinae). Enzymemediated production from acetate precursors. J Chem Ecol. 1989;15(5):1501-11.

19. Hindler AH, Jorgensen JH. Procedures in antimicrobial susceptibility testing. In: Mahon CR, Manuselis Jr $\mathrm{G}$, editors. Textbook of diagnostic microbiology. Philadelphia: WB Saunders Company; 1985. p. 69-71.

20. Hölldobler B, Wilson EO. The ants. Cambridge, Massachusetts, USA: Belknap Press; 1990.

21. Hölldobler B, Engel-Siegel H. On the metapleural gland of ants. Psyche. 1985;91:201-24.

22. Beattie AJ, Turnbull C, Hough T, Knox RB. Antibiotic production: a possible function for the metapleural glands ants (Hymenoptera: Formicidae). Ann Entomol Soc Am. 1986;79(3):448-50.
23. Attygalle AB, Siegel B, Vostrowsky O, Bestmann HJ, Maschwitz U. Chemical composition and function of the metapleural gland secretion of the ant, Crematogaster deformis Smith (Hymenoptera: Myrmicinae). J Chem Ecol. 1989;15(1):317-29.

24. Inagaki H, Akagi M, Imai HT, Taylor RW, Kubo T. Molecular cloning and biological characterization of novel antimicrobial peptides, pilosulin 3 and pilosulin 4, from a species of the Australian ant genus Myrmecia. Arch Biochem Biophys. 2004;428(2):170-8.

25. Mendes MA, de Souza BM, Marques MR, Palma MS. Structural and biological characterization of two novel peptides from the venom of the neotropical social wasp Agelaia pallipes pallipes. Toxicon. 2004;44(1):6774.

26. Yan L, Adams ME. Lycotoxins, antimicrobials peptides from venom of the wolf spider Lycosa carolinensis. J Biol Chem. 1998;273(4):2059-66.

27. Budnik BA, Olsen JV, Egorov TA, Anisimova VE, Galkina TG, Musolyamov AK, et al. De novo sequencing of antimicrobial peptides isolated from the venom glands of the wolf spider Lycosa singoriensis. J Mass Spectrom. 2004;39(2):193-201.

28. Corzo G, Escoubas P, Villegas E, Barnham KJ, Weilan $\mathrm{HE}$, Norton RS, et al. Characterization of unique amphipathic antimicrobial peptides from venom of the scorpion Pandinus imperator. Biochem J. 2001;359(Pt 1):35-45.

29. Rosengaus RB, Lefevre ML, Traniello JFA. Inhibition of fungal spore germination by Nasutitermes: evidence for a possible antiseptic role of soldier defensive secretions. J Chem Ecol. 2000;26(1):21-39. 